\title{
ЕСХАТОЛОГІЧНІ ТА АПОКАЛІПТИЧНІ НАСТРОЇ СЕРЕД НАСЕЛЕННЯ СХІДНОГО ПОДІЛЛЯ У 1920-Х РОКАХ
}

Анотація: У статті розкриваються головні прояви есхатологічних та апокаліптичних настроїв серед населення Східного Поділля у 1920-х рр. Очікування наближення «останніх часів» завжди було достатньо характерною ознакою життл православного населення. Теми кіния світу, Страшного суду, настання Царства Небесного є важливою частиною християнських вірувань. Особливо актуальними вони стають у часи переслідування християн, погіршенні економічної та політичної обстановки, появі різноманітних природних катаклізмів тощо. На території Поділля у 20-х роках XX ст. комуністична влада проводила антирелігійну політику, здійснювала переслідування церковних людей, різко змінювала звичний уклад життя. Відповідна політика стала поштовхом до посилення есхатологічних настроїв серед жителів краю, прихід радянської влади сприймався як здійснення апокаліптичних пророцтв. Частина віруючого населення була впевнена у швидкому настанні Страшного суду та покаранні безбожних комуністів, гонителів церкви.

У роботі аналізуються есхатологічні настрої православного населення, переважно прибічників старослов'янської церкви. Посилення таких настроїв було пов'язане із загальним релігійним рухом на Поділлі на початку 1920-х рр. Виникали різноманітні оповідання, перекази, легенди, пісні про швидке настання «кіния світу» та прихід Антихриста. Крім народно-побутових уявлень, мали місце спроби трактувати соціалізм як антихристиянську владу на основі иерковнобогословської традиції.

Ключові слова: есхатологічні настрої, релігійний рух, Антихрист, «останні часш», безбожна влада, Апокаліпсис

За умов ускладнення соціально-економічної та морально-політичної ситуації, у людей часто виникає прагнення оцінити суспільні процеси на основі моральних принципів і релігійних переживань. Зокрема, у християнському середовищі починають посилюватись есхатологічні й апокаліптичні настрої, тобто все частіше віруючі починають розмірковувати про так званий кінець світу та Страшний суд. Поява різноманітних катаклізмів, погіршення загальної обстановки розцінюється як наближення апокаліптичних подій. Подібні настрої мали місце серед населення Поділля у 20-х роках ХХ ст. Саме в цей час, незважаючи на антирелігійну політику держави, виникає значний релігійний рух, частиною якого стало поширення есхатологічних та апокаліптичних ідей.

Проблема посилення есхатологічних настроїв серед подільського населення 1920-х рр. $€$ недостатньо вивченою. Важливі відомості нам подають відомі етнографи, що жили та

\footnotetext{
* Панасюк Михайло Петрович - аспірант кафедри історії та культури України Вінницького державного педагогічного університету імені Михайла Коцюбинського (м. Вінниця, Україна) ORCID: https://orcid.org/0000-0003-3497-1270; e-mail: pm.vin@ukr.net
} 
працювали у зазначений період, зокрема Никанор Дмитрук ${ }^{1}$, Олена Пчілка², Павло Попов ${ }^{3}$, Василь Кравченко ${ }^{4}$. Народна релігійність 20-х рр. ХХ ст. на Поділлі висвітлювалась у працях Л. Бабенко ${ }^{5}$, О. Ігнатуші ${ }^{6}$, А. Киридон ${ }^{7}$, В. Дяківа ${ }^{8}$, М. Олійника ${ }^{9}$, М. Панасюка ${ }^{10}$, хоча проблем очікування апокаліптичних подій торкались у повній мірі не всі з перерахованих дослідників, їх роботи мають важливе значення для з'ясування особливостей духовно-психологічного середовища, в якому формувались відповідні устремління. Значну увагу проблемі висвітлення есхатологічних настроїв приділив С.І. Дровозюк. Так у праці «Масовий релігійний рух на Поділлі у 1920-х рр. Історіографія проблеми» ${ }^{11}$ науковець аналізує роботи вітчизняних дослідників, що торкалися даної проблематики. Автор коментує роботу С. Якимовича «3 есхатологічних настроїв», зокрема твердження, що апокаліптичні настрої з'явились ще 1921 р. та були невіддільними від антикомуністичних політичних поглядів ${ }^{12}$.

Есхатологічні настрої були притаманні жителям багатьох регіонів України. Наприклад, дослідник В.А. Савченко у книзі «Неофициальная Одесса епохи непа (март 1921 сентябрь 1929 гг.)» ${ }^{13}$ змальовуючи релігійне життя Одеси, повідомляє про поширення у 1924-25 рр. в місті різного роду чуток, переказів про настання кінця світу та прихід Антихриста, якого іноді ототожнювали з Леніним. Також автор вказує на активізацію діяльності на півдні України релігійних об'єднань баптистів, євангелістів, адвентистів, молокан і різного роду сект. Як відомо, окремі з них перебували на достатньо вагомих апокаліптичних позиціях. Важливу інформацію з даного питання нам подає О.П. Тригуб у дисертаційній праці «Російська православна церква в радянській Україні 20-30-х рр. XX ст.: інституційний розкол та міжконфесійні відносини» ${ }^{14}$, де він розповідає про очікування кінця світу жителями різних територій України. Автор характеризує діяльність Істино-

\footnotetext{
${ }^{1}$ Дмитрук Н. Про чудеса на Україні року 1923-го // Етнографічний вісник. 1925. № 1. С. 50-61.

${ }^{2}$ Пчілка О. Українські легенди останнього часу // Етнографічний вісник. 1925. № 1. С. 41-49.

${ }^{3}$ Попов П. До текстів так званих «Калинівських пісень» // Етнографічний вісник. 1927. № 4. С. 8-30.

${ }^{4}$ Кравченко В. «Псальми», що в 1923-24 рр. співали прочани під час подорожувань до різних чудес // Етнографічний вісник. 1927. № 4. С. 71-78.

${ }_{5}^{5}$ Бабенко Л.Л. Механізми та особливості ліквідації православних монастирів в Україні в 1920-х рр. // Гуржіївські історичні читання. 2011. Вип. 4. С. 168-170.

${ }^{6}$ Ігнатуша О.М. Інституційний розкол православної церкви в Україні: генеза і характер (XIX ст. - 30-ті рр. ХХ ст.). Запоріжжя. 2004. 440 с.

${ }^{7}$ Киридон А. Держава - Церква - Суспільство: інверсна трансформація в Україні: Монографія. Рівне: РІС КСу, 2011. 216 с. (Серія: Актуальні проблеми вітчизняної та всесвітньої історії).

${ }^{8}$ Длків В. Народна релігійність українців в умовах більшовицької окупації 1920-х років // Народознавчі зошити. 2013. № 3 (111). С. 411-434.

${ }^{9}$ Олійник М.П. Прояви чудес та оновлення ікон на Поділлі в 1923 р. та боротьба влади 3 цим явищем // Освіта, наука і культура на Поділлі. 2013. № 20. С. 509-519.

${ }^{10}$ Панасюк М.П. Релігійна творчість подолян в 1920-х рр. // Наукові записки Тернопільського національного педагогічного університету імені Володимира Гнатюка. Серія: Історія. 2019. № 2. С. 123-127.

${ }^{11}$ Дровозюк C.I. Масовий релігійний рух на Поділлі у 20-х рр. XX ст. Історіографія проблеми // Наукові записки ВДПУ імені Михайла Коцюбинського. Серія: Історія. 2002. № 4. С. 234-240.

${ }^{12}$ Ibid. C. 236.

${ }^{13}$ Савченко В.А. Неофициальная Одесса эпохи непа (март 1921 - сентябрь 1929 гг.). Москва: Российская политическая энциклопедия (РОССПЭН), 2012. 287 с.

${ }^{14}$ Тригуб О.П. Російська православна церква в радянській Україні 20-30-х рр. ХХ ст.: інституційний розкол та міжконфесійні відносини: Дис... д. іст. наук. Київ. 2010. 510 с.
} 
православної церкви й істино-православних християн, у середовищі яких активно пропагувались апокаліптичні ідеї, а більшовизм сприймався як влада Антихриста, наводить приклади діяльності на Вінниччині сект - іоаннітів і «червонодраконівців», у яких ідеї близького настання кінця світу були домінуючими.

Незважаючи на окремі дослідження та розвідки, проблема посилення есхатологічних настроїв на Поділлі потребує подальшого вивчення, тому метою даної статті є висвітлення проявів есхатологічних та апокаліптичних настрої серед подільського населення у 1920-х роках. Головними завданнями роботи є з'ясування особливостей сприйняття народною свідомістю християнського вчення про «останні часи», в яких формах проявлялись апокаліптичні настрої, як чином трактувалась більшовицька влада віруючим населенням, визначення причин посилення есхатологічних настроїв подолян.

Есхатологія - це доктрина про існування кінця світу, місце людини в ньому (від

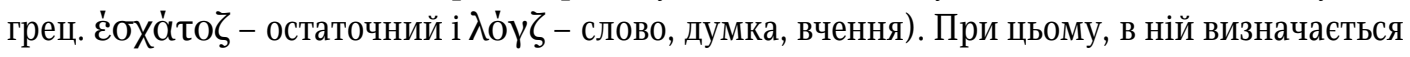
доля людини перед кінцем світу, під час його настання та що чекає людство після завершення світової історії, апокаліптичні події - це головним чином катаклізми та перипетії, що будуть супроводжувати наближення останніх часів. Есхатологія передбачає фіналістське осмислення ідеї розвитку людства, характеризує цілісність сприйняття історичного часу. На думку М. Бердяєва, історія по своїй суті есхатологічна, тому що вона передбачає завершальний фінал, настання катастрофічних подій, після чого починається якийсь новий світ, нова дійсність. Також філософ звертає увагу на те, що виникнення апокаліптичних настроїв не означає, що хронологічно близький кінець світу ${ }^{15}$.

Система поглядів про «останні часи» є невід'єною складовою християнського вчення. 3 якими викликами зустрінеться людство при завершенні світової історії розповідається у головній книзі християнства - Біблії. Окремі книги Старого заповіту, а також Євангеліє та апостольські послання навчають християн бути готовими зустріти другий прихід у світ Месії-Христа. Найбільш повно про події, пов'язанні з кінцем світу повідомляє таємнича книга Біблії «Одкровення Іоанна Богослова», або «Апокаліпсис». Головна ідея книги повідомити, що чекає людство наприкінці світової історії. Відповідно до текстів «Одкровення», перед кінцем світу настануть важкі часи, розпочнуться великі гоніння на християн, а владу у всьому світі захопить Лжемесія - Антихрист. Тому християни будь-яку владу, що переслідує церкву, називали не лише безбожною, а й владою Антихриста.

3 приходом більшовицької влади в Україні розгорнулася широка атеїстична кампанія, були введені значні обмеження релігійної діяльності, розпочалися переслідування священників, монахів, парафіян. Тому в очах віруючих комуністичні діячі стали тими служителями Антихриста, про які розповідається у біблійних книгах.

Про поширення апокаліптичних та есхатологічних настроїв серед населення Поділля свідчать численні легенди, оповідання, перекази, пісні, що масово поширювались в краї у 20-х роках XX ст. Причиною їх появи стала політика радянської влади щодо церкви та релігії, окремі соціально-економічні перетворення, традиції православної культури й особливості менталітету тодішнього українського населення.

\footnotetext{
${ }^{15}$ Бердяєв M. Війна та есхатологія // Психологія $\quad$ i $\quad$ суспільство. 2015. № 4. $\quad$ C. $7 . \quad$ URL: http://nbuv.gov.ua/UJRN/Psis_2015_4_3
} 
Вже з самого початку становлення радянської влади та запровадження антицерковної політики серед віруючих почали з'являтися думки, що більшовицька влада - це влада від Антихриста, яка не буде тривалою. Значна кількість православних віруючих оголосила про скоре падіння «влади Антихриста» і кінець світу. Вони пророкували, що комуністична влада протримається три 3 половиною роки, відповідно до текстів «Одкровення» ${ }^{16}$. Хоча їх очікування не справдились, есхатологічні настрої лише посилювались. Певну роль 3 цьому відіграв голод 1921-23 pр., саме тоді багато жителів переважно сільської місцевості усвідомили, що потрібно попереджати кару божу, можливо й кінець світу ${ }^{17}$.

На території Поділля ідеї кінця світу масово поширювались під час епідемії так званих релігійних чудес. Про це свідчать сучасники тих подій, відомі етнографи Никанор Дмитрук, Олена Пчілка, Павло Попов. Олена Пчілка у праці «Українські народні легенди останнього часу» $^{18}$, стверджує, що чудеса дали привід для утворення розмаїтих легенд, серед них легенди про Антихриста, в яких повідомлялося, що він незабаром народиться, а можливо вже народився. На думку дослідниці, ці простодушні релігійні думки були достатньо ревниві у своєму вираженні.

Никанор Дмитрук у роботі «Про чудеса на Україні року 1923-го» наводить тогочасні народні легенди: «Як потрібно до Страшного Суду готовитись» та «Проскурки». У них містяться повчальні рекомендації, як захиститися від Антихриста, що незабаром прийде. Дослідник помічає, що слово Антихрист у народній вимові звучало як Анцихрист, Ганцихрист $^{19}$.

Павло Попов у роботі «До текстів так званих “Калинівських пісень”» наводить приклади народних пісень про наближення Страшного суду. Одна із них називається «Пісня про Анцихриста» ${ }^{20}$, ось невеликий уривок 3 неї:

Земля буде сопіти

Дванадцять громів буде гриміти.

Весь світ зміниться

I все переміниться.

Буде ходити по під хати Анцихрист,

Але його не пускати.

Бо він буде пичатувати

I в свою книгу записувати.

В іншій пісні із цього ж циклу знаходимо слова:

Чи знаєте люди, який сьогодні день?

Що прийде Спаситель судити людей.

Згадуваний етнограф пісні подібного напрямку називає «Калинівські есхатологічні пісні» ${ }^{21}$.

\footnotetext{
${ }^{16}$ Шугаєва Л. Релігійні утворення Істинно-Првославної церкви й істинно-православних християн як форма протистояння тоталітаризму // Проблеми історії України: факти, судження, пошуки. 2006. № 15. С. 423-435. URL: http://resource.history.org.ua/publ/pro_2006_15_423

${ }^{17}$ Дмитрук Н. Про голод на Україні року 1921-го // Етнографічний вісник. 1927. № 4. С. 82.

${ }^{18}$ Пчілка О. Українські легенди останнього часу // Етнографічний вісник. 1925. № 1. С. 53.

${ }^{19}$ Дмитрук Н. Про чудеса на Україні року 1923-го // Етнографічний вісник. 1925. № 1. С. 60.

${ }^{20}$ Попов П. До текстів так званих «Калинівських пісень» // Етнографічний вісник. 1927. № 4. С. 10.

${ }^{21}$ Попов П. До текстів так званих «Калинівських пісень» // Етнографічний вісник. 1927. № 4. С. 18.
} 
Зростання актуальності тематики про «останні часи» було пов'язане з чудом у так званій Йосафатовій долині (біля сучасного села Голичинці, Шаргородського району, Вінницької області), де за народним повір'ям з'явилась Божа Матір і закликала ставити хрести. Сама ідея Йосафатової долини, за прикладом аналогічної долини у Палестині - це місце, де воскреснуть мертві, а значить відбудеться Суд Божий. Якщо у даній місцевості з'являється така долина, то у свідомості багатьох людей кінець світу має незабаром наступити. Тому долина хрестів стала підтвердженням швидкого приходу Антихриста, а воскресіння мертвих і хрести це прямі ознаки Страшного суду. Згадуваний нами етнограф Никанор Дмитрук повідомляв, що такі ідеї приваблювали селянство Волині та Поділля ${ }^{22}$. А Володимир Дяків підкреслює, що завдяки поширенню чуток по Голичинське чудо, у фольклорній інтерпретації набувають сюжетної розбудови слова 3 «Книги пророка Йоіля» про «Суд у Йосафатовій долині»: «Нехай пробудяться й зійдуть народи в долину Йосафатову, бо сяду Я там, щоб судити всі народи з довкілля. Пошліть на роботу серпа, бо жниво дозріло, приходьте, зійдіть, бо чавило наповнене, кадки переливаються, - бо зло їхнє розмножилось!» ${ }^{23}$.

Для паломників, що відвідували місця появи чудес, місцеві жителі влаштовували загальні обіди, під час яких проводились бесіди на тему Апокаліпсису, співали есхатологічних релігійних пісень, читали молитви. Організовували також дитячі обіди, вважаючи, що Бог швидше послухає дітей, які не встигли нагрішити. Дитяча молитва повинна була випросити життя людське та віддалити день Страшного суду.

Апокаліптичні настрої посилювались у зв'язку з поширенням так званого «сектантства». Представники тодішньої комуністичної влади так класифікували будь-які релігійні об’єднання, окрім традиційних церков. На Поділлі діяли різні релігійні організації, окремі 3 них стояли на позиціях швидкого наближення Страшного суду. Наприклад, розгорнула діяльність секта Іоаннітів. Послідовники священика Іоанна Кронштадтського проповідували, що друге пришестя Христа уже відбулося в образі священика, але мало хто це помітив, тому кінець світу вже близький. Послідовники негативно ставилися до приватної власності, свою власність члени громади повинні віддавати у розпорядження «святих» батюшки Іоанна ${ }^{24}$. Адепти секти стверджували, що у 1923 р. наступить кінець світу, закликали спасати душі, роздаючи майно, самі приймали цінні речі від населення. Але не брали радянських грошей, вважаючи їх «грошима антихриста» ${ }^{25}$.

У звітній доповіді Тульчинського окрвиконкому за травень 1923 р. повідомлялося, що дана релігійна група активно діяла на території Тульчинської та Гайсинської округ, а центром їхньої діяльності було село Паланка Ладижинського району Гайсинської округи. О.П. Тригуб вказує, що кількість іоаннітів на території Поділля наприкінці 1920-х рр. становила близько 150 осіб $^{26}$. Найбілыше під їх впливом перебували неосвічені жінки. У згадуваній вище доповіді Тульчинського окрвиконкому також повідомляється про секту сіонітів (іудеїв), послідовники якої цілими сім'ями направились до Палестини, очевидно зустрічати кінець світу. Останній

\footnotetext{
22 Дмитрук Н. Калинівські пісні. Етнографічний вісник. 1925. № 1. С. 65.

${ }^{23}$ Дяків В. Народна релігійність українців в умовах більшовицької окупації 1920-х років // Народознавчі зошити. 2013. № 3 (111). С. 428.

${ }^{24}$ Шугаєва Л. Іоанніти - течія хіліастично-есхатологічного спрямування православного походження // Українське релігіезнавство. 2006. № 39. С. 150. URL: http://nbuv.gov.ua/UJRN/Ukrr_2006_39_17

${ }^{25}$ Державний архів Вінницької області (ДАВіО). Ф. Р-925. Оп. 8. Спр. 47. Арк. 9.

${ }^{26}$ Тригуб О.П. Вказ. пр. С. 310.
} 
раз їх бачили у м. Смотрич Подільської губернії, де вони збирались перейти кордон ${ }^{27}$. Дорослі чоловіки при цьому здійснили обряд обрізання, на основі чого можна зробити припущення, що до цієї групи належали представники різних національностей.

У середовищі православних віруючих мали місце погляди згідно з якими радянська влада трактувалася не просто антицерковною, а конкретно владою Антихриста, а соціалізм це лад, який настав для боротьби з релігією. Підтвердження такої позиції знаходимо в окремих документах Вінницького окружного партійного комітету. У поле зору тодішніх партійних функціонерів попало так зване «Звернення» до віруючих, головна ідея якого влада рад - влада Антихриста. У документі стверджується, що в церкві діє Дух Божий, Дух Святий, але проти нього веде боротьбу дух соціалізму, дух злий, дух нечистий, що спотворює людську мораль. Автор даного документу оцінює більшовизм на основі традицій православної богословської думки, вважаючи його знаряддям Сатани ${ }^{28}$. Називали радянську владу «владою Антихриста» й подільські священики Ферапонт Подолянський та Олександр Лотоцький, які зазнали переслідувань і репресій з боку влади ${ }^{29}$.

Хоча апокаліптичні настрої були доволі поширеним явищем, трактування більшовизму, як влади Антихриста, сприймалося лише частиною віруючих. Незважаючи на утиски й обмеження релігійних прав, далеко не всі віруючі вважали, що Страшний суд уже наступає, але необхідно визнати, що відповідні ідеї мали місце у народній свідомості. Вони також відобразились у діяльності так званої Істинно-православної церкви, що сформувалася у 19271928 роках і діяла нелегально. Поштовхом для їі утворення стала позиція місцеблюстителя патріаршого престолу митрополита Сергія (Старогородського) про лояльність до радянської влади. Служителі Істино-православної церкви відкидали співпрацю з радянською державою, як владою Антихриста, різко негативно ставились до колективізації, відмовлялися працювати на радянських підприємствах і в установах, забороняли дітям віруючих відвідувати школу. Осередки цієї церкви виникли фактично по всій території підрадянської України, у тому числі на Поділлі. Особливо сильними вони були на Київщині, Чернігівщині, Харківщині, Дніпропетровщині, Одещині, Херсонщині, Миколаївщині ${ }^{30}$.

Таким чином, у 20-х рр. XX ст. на території Подільського краю мало місце поширення есхатологічних та апокаліптичних настроїв серед населення. Поширювалися пісні, легенди, оповідання, передання про прихід Антихриста, кінець світу та Страшний суд.

Подібні настрої найбільше були притаманні православним віруючим, переважно прихильникам так званої «тихонівської церкви». Вони були зумовлені антицерковною політикою радянської влади, релігійними традиціями жителів краю, уявленнями про справедливість, відповідальність і покарання за проступки.

Поширення ідей про наближення кінця світу було частиною загального релігійного руху, що мав місце на Поділлі на початку 1920-х рр. Ці ідеї були представленні, як на рівні народно-побутових явлень, так і обгрунтовувались церковно-богословськими категоріями. В окремих випадках есхатологічні настрої були пов'язані з антибільшовицькими політичними поглядами жителів краю.

\footnotetext{
${ }_{27}$ ДАВіО. Ф. Р-925. Оп. 8. Спр. 47. Арк. 10.

${ }_{28}^{28}$ ДАВіО. Ф. П-29. Оп. 1. Спр. 48. Арк. 13.

${ }^{29}$ Тригуб О.П. Вказ. пр. С. 316.

${ }^{30}$ Ibid. C. 332-336.
} 
Есхатологічні й апокаліптичні настрої, а також ставлення до радянської влади знайшли відображення у діяльності Істино-православної церкви (катакомбної), що сформувалась наприкінці 1920-х рр.

Есхатологічні настрої мали місце в інших регіонах України, вони свідчили про формування відповідного відношення у віруючого населення до радянської влади, реакцією на посилення антирелігійної та антицерковної політики більшовизму.

\title{
Mykhailo Panasiuk
}

\section{The growth of eschatological and apocalyptic sentiments among the population of Eastern Podillia in the 1920s}

\begin{abstract}
This article reveals the main manifestations of eschatological and apocalyptic sentiments among the population of Eastern Podillia in the 1920s. The anticipation of the approach of «the last days» has always been a rather characteristic feature of the life of the Orthodox population. Themes of the «the end of the world», the Last Judgment, the coming of the Kingdom of Heaven are an important part of Christian beliefs. They become especially relevant in the times of persecution of Christians, deteriorating economic and political situation, the emergence of various natural disasters. On the territory of Podillia in the 1920s. the communist government pursued an anti-religious policy, persecuted church people, and dramatically changed the way of life.

Appropriate actions were the impetus for the strengthening of eschatological sentiments among the inhabitants of the region, the arrival of Soviet power began to be perceived as the implementation of apocalyptic events. The part of the faithful was convinced of the imminent coming of the Last Judgment and the punishment of ungodly communists, persecutors of the church.

The article analyzes the eschatological sentiments of the Orthodox population, mainly adherents of the Old Church Slavonic. The strengthening of such sentiments was associated with the general religious movement in Podillia in the early 1920's. The information about the so-called miracles was especially actively spread: the renewal of icons, the appearance of crosses, the appearance of saints. The most famous among them were the Kalinov Cross and the apparition of the Mother of God in the Jehoshaphat Valley. Thousands of believers began to visit places of miracles, and during such pilgrimages apocalyptic prophecies became more and more relevant. There were various stories, legends, stories, songs about the imminent coming of the «end of the world» and the coming of the Antichrist. In this way, the population of the region reacted to the strengthening of atheistic policies. In addition to popular ideas, there have been attempts to interpret socialism as an anti-Christian government based on the church-theological tradition.
\end{abstract}

Keywords: eschatological sentiments, religious movement, Antichrist, «The last days», ungodly government, Apocalypse 